for the Trust Territory of the Pacific Islands are being continued. The major part of the field-work on the atoll programme has been completed, and $\mathrm{H}$. J. Wiens is now working on an interpretative study of man and Nature in coral atolls. The volume, "Island Bibliographies", by M. H. Sachet and F. R. Fosberg, was published as Publication No. 335 of the National Academy of Sciences-National Research Council, and eleven numbers of the Atoll Research Bulletin were issued during the year. The Invertebrate Consultants Committee for the Pacific held its annual meeting in Honolulu on March 9-10, when the collection was authorized of sufficient numbers of the carnivorous snails on the island of Agiguan to permit experimental releases in several areas of the 'Trust Territory and on Guam for control of the giant African snail, Achatina fulica. Support was continued for the control of the Palau beetle, four further volumes in the "Insects of Micronesia Series" were published, and, in addition to other research on the rhinoceros beetle, a three-year research survey is being made into rhinoceros beetle diseases. Five further reports were issued under the programme of scientific investigations in the Ryukyu Islands, and the final report on the study of the cultural changes in Olsinowa since 1945 was also distributed. Biological investigations include the initiation of a threeyear biological and ecological study of Pacific island rats at Panape in the Eastern Caroline Islands, and more than two thousand species of marine and freshwater fishes and marine invertebrates were collected at 280 stations in the Palau Islands. Through its Conservation Committee for Micronesia the Board is concerned with the preservation of endangered species, the establishment of parks and reserves and the control of the introduction of exotic species. Plans are being made for four conservation reserves representative of Guam soils, plants and wild-life, and studies were made of the wild-life situation in Malaya and Burma.

\section{University of Leeds Brotherton Library}

THE annual report of the librarian on the Brotherton Library at the University of Leeds (pp. 11. Leeds: University Library, 1956) for 1955-56 records a total holding of 567,121 volumes at June 30 , 1956, of which 398,854 were in the Brotherton Library, 42,350 in the Brotherton Collection, 32,793 in the Medical Library, 36,540 in the Agricultural Library, 6,466 in the Textile Library, 13,390 in that of the Institution of Education and 24,554 in the twenty-nine Departmental Libraries. Loans to readers totalled 97,170 and inter-library loans 4,437 . Owing to financial stringency, the Library Cornmittee assumed financial responsibility and central administration for ordering books for the Library of the Department of Adult Education and of Extra-mural Studies from the beginning of the quinquennium, the actual management of the Library remaining with the Department. This arrangement has now been terminated, and it is hopod that an assistant librarian will before long be appointed.

\section{Yale Medical Library}

THE annual report of the Yale Medical Library for the academic year 1955-56 (pp. 34. New Haven, Conn.: Yale Medical Library, 1956) comments on developments in electronic and other types of memory units for handling and storing information, of which it is hoped the Library will be able to take advantage in the next few years. Results of a study on moder- ately used periodicals designed to show whether it would be advantageous to continue binding or to shelve them in compact storage boxes were inconclusive, and binding is being continued. The recorded circulation increased by 37 per cent over the previous year, and it appears that new circulation procedures have contributed to a net gain of 36 per cent in availability. The total number of volumes at the end of the year was 289,091, compared with 282,141 in the previous year.

\section{The National Museum, Bloemfontein}

THE annual report of the National Museum at Bloemfontein for the year ended March 31, 1956 (pp. 16. Bloemfontein : National Museum, 1956), urges the need for an extension of two wings to the present building for purposes of additional exhibition and storage space as well as the provision of laboratories. The establishment of a Committee of Heads of State Aided Institutions has proved a most important and constructive event, bringing the Museum into close contact with the Department of Education, Arts and Science. New displays include a historic printing press and dioramas of wildebeest and other Free State antelopes. The new lecture theatre has been used to great advantage, and plaster casts of dinosaur tracks from Basutoland form an important acquisition.

\section{Kumasi College of Technology, Ghana}

The Kumasi College of Technology came into legal being on October 6, 1951. It has now published an attractive Calendar setting out particulars of its courses, fees, facilities for student activities, as well as the names and appointments of its academic staff. It is pleasing to see Africans serving as deputies to British people in some departments and equally pleasing to see British people serving as deputies to Africans in others. Among the courses offered are four-year rural-subjects courses in the Department of Agriculture, the facilities including a thirty-acre arable farm and a market garden of three acres. The Department of Commerce offers courses in accountancy, secretaryship and administration and estate management. Besides degree courses in engineering, the College offers a course in surveying. Other Departments include those of Pharmacy, Science and General Studies, and Teacher 'Training, the latter including courses in physical education, housecraft, arts and crafts, and music. Copies of the Calendar may be obtained from the London Office, 29 Tavistock Square, London, W.C.I.

\section{Research at the University of Birmingham}

The twenty-seventh annual report of the Research Committee of the University of Birmingham (pp. 97. Birmingham: The University, 1957) gives a general survey of research completed and in progress during the academic year 1955-56, with lists of publications and of theses approved for higher degrees, classified according to their departments of origin. Since the beginning of the session 1955-56 the allocation of research grants to individual members of staff has been carried out by the faculties, to which block allocations have been made for that purpose. The Committee has continued to make individual grants from the Field Research and Expeditions Fund to members of the Departments of Geology, Ancient History and Archæology, and Extra-Mural Studies. 